\title{
An Analysis of the Hanson-Liethen Sliding Scale Cost Recovery Model for College Tuition: A Case Study
}

\author{
Michael T. Miller \\ Professor of Higher Education, University of Arkansas \\ 324 Graduate Education Building, Fayetteville, AR 72701, USA \\ Tel: 479-575-3208Ｅmail: mtmille@uark.edu
}

Everrett A. Smith

Assistant Professor, Higher Education, University of Cincinnati

610P Teacher-Dyer Hall, Cincinnati, OH 45221, USA

Tel: 513-556-8028Ｅmail: everrett.smith@uc.edu

Received: June 16, 2017

doi:10.5296/gjes.v3i2.11409
Accepted: July 7, 2017

Published: July 20, 2017

URL: https://doi.org/10.5296/gjes.v3i2.11409

\begin{abstract}
Public colleges and universities rely increasingly on tuition to subsidize their operations, and how they price their tuition is important for many reasons, including who can access higher education, the financial stability of the institution, what labor costs can be paid, etc. In the early-1970's, two scholars created a sliding scale for tuition pricing based on the assumption of state-citizenship. As costs have risen in higher education and public subsidies have not grown, there is a need to reconsider some of these tuition pricing models and to examine their potential to secure the financial stability of public higher education. Through an analysis of tax-related and tuition pricing data, the current analysis identified that the Hanson-Liethen sliding scale model does have several distinct advantages over the incremental-based tuition pricing at one case study institution, but that the model did not return significantly more money to the institution, thus, not providing a strong rationale for the model's adoption at the case study institution.
\end{abstract}

Keywords: Tuition price setting, Higher education finance, College revenue 


\section{Introduction}

There is a renewed national interest in exploring how higher education is paid for, and by whom. State legislatures use performance funding as a tool to try and assure specific action items, such as graduation rates (Sanford \& Hunter, 2011) or to assure students major in STEM fields (Dougherty \& Reddy, 2011; Fincher, and other legislatures are working to find ways to make higher education free (Jaschik, 2017). Although the free-tuition movement has been primarily situated in the two-year college realm, other institutions have attempted to use tuition differently, either lowering tuition levels to ensure accessibility, or increasing tuition levels to assure the financial stability of an institution. Some very high profile institutions have even explored going tuition free to focus on enrolling the most talented and capable students rather than just students who have an ability to pay; similarly, state legislatures have pursued free tuition to ensure access (Jaschik, 2017).

The exploration of tuition models is far from a new pursuit. During the expansive period of the late-1960s and early-1970s, a number of scholars and academic leaders worked to identify different approaches to paying for college. These ranged from complete state-subsidies to strongly aligned systems plans that made use of rationale decision making to assign certain majors, and costs, to different types of campuses. A number of these models were assembled in Carbone (1974) report for ACT describing alternative tuition systems, including models such as a national tuition bank and resident student fee remission models. Two in particular are relevant in the current environment of higher education where students are crossing state boundaries at a high rate, including the sliding scale multiple criteria model, also referred to as the Blackbury Model and the sliding scale single criterion model, known as the Hanson-Liethen Model.

The Blackbury and Hanson-Liethen models both focus on criteria to which tuition payment levels are assigned to students. As the Blackbury model involves multiple criteria, an initial examination of the Hanson-Liethen model must first be completed before expanding to multiple criteria.

The Hanson-Liethen Sliding Scale Cost Recovery Formula was developed by David Hanson and Michael Liethen at the University of Wisconsin. The model assumes that residents, as dependents of tax paying guardians, pay for college expenses by virtue of paying state taxes. Therefore, those who are new to a state are required to pay a higher level of tuition as they have not paid the same level of taxes contributing to college costs. The purpose for conducting the study was to determine if the Hanson-Liethen tuition model financially and equitably supports a stronger financial situation for a public university.

\section{Collegiate Tuition Models}

Various forms of 'tuition' have been part of the history of higher education, as the root of the word is derived from the idea of granting guardianship. Early institutions would take over for the parent in the raising of a child, and would typically take some form of barter for assuming this role. The modern interpretation of tuition has evolved from a supplement to a state allocation for higher education, to a larger proportion of the total cost involved in educating a 
student. In public higher education, these tuition levels are approved variously by individual institutional administration, boards of trustees, state higher education systems, or even state legislatures (Burgess, 2009).

Private higher education institutions make uses of tuition charges in a very different way from public institutions. Instead of a supplemental charge to complete a total actual cost for an education, private institutions typically rely on tuition charge levels to assume the majority of an actual cost. Private institutions also utilize tuition rates differently. For some institutions, for example, they charge higher rates for different types of programs, such as online education programs, and then charge a different rate for residential programs. For some institutions, the use of online program tuitions allows for a significant revenue generation that subsidizes residential programs that are not financially viable (Miller \& Morris, 2008).

Rusk and Leslie (1978) argued that tuition is truly a state policy subsidy for higher education, something to be manipulated to create or deny access. Paulsen (1991), somewhat conversely, argued that tuition is directly dependent on the price of other charges incurred at the institution, and as a result, is a direct cost for the benefit of the experience. In the Paulsen explanation of tuition, as other charges such as technology, energy to heat or cool a room, etc. increase, tuition rises at a similar rate. Doyle (2012) confirmed the ability of a state legislature to create policy that can influence tuition price setting, but also introduced the variable of private postsecondary education as a competitive variable that force public institutions to respond to a competitive pricing.

Several activists, politicians, and researchers have advocated for a change in college tuition-setting practices (Archibald \& Feldman, 2011). Less expensive tuition could come with certain location restraints, as many students and their families make decisions about attendance based on both cost and the locality of the institutions under consideration (Miller \& Smith, 2017). As stakeholders consider a shift in the way that tuition is set, exploration for what that could mean for state populations are important. Tuition has risen faster than the average family median income in most states (Mitchell, Leachman, \& Masterson, 2016), and as colleges attempt to identify new opportunities to address affordability concerns, families from middle and upper middle income backgrounds especially may be reluctant to wait for institutional solutions and instead, consider colleges in different states that offer competitive tuition prices.

Part of the discussion and concern about the cost of college is also based on evidence that student debt has increased substantially and that the cost of college has reached prices that are largely unaffordable for many students (Baum \& Lee, 2017). Who should pay for public higher education has been an argument with little conclusion, and today, students contribute more to the cost of tuition than state governments (Douglas-Gabriel, 2015). Many stakeholders have argued that students and their families should provide some type of payment for their education, and though that often translates into financial payment, other experts are attempting to develop and introduce alternative approaches to tuition-setting that could relieve concerns about the cost of college attendance, and at the same time, help keep public colleges both competitive and in position to serve state residents. 


\section{Mll Macrothink}

Global Journal of Educational Studies

ISSN 2377-3936

2017, Vol. 3, No. 1

There are a few states that have made attempts to address tuition concerns through more innovate tuition modeling and policies. In North Carolina, policy makers implemented decentralized tuition policies that allowed institutions to set college prices based on campus mission and values (Harris, 2007). An intention of the policy was to help students make a more informed decision about the college that they decided to attend by evaluating costs and purpose at the same time. Nonetheless, this type of deregulation policy does not reduce actual costs, and is a choice focused approach to addressing tuition. Colorado adopted a voucher-based system that provides state and select private colleges and universities with vouchers to operate; and state residents received stipends in order to off-set the cost of tuition and increase access for those who need it the most (WICHE, 2009). However, Hillman, Tandberg, and Gross (2014) found that there was little evidence that suggest that this model provided the intended cost efficient effects and increase in accessibility as initially proposed for traditional four-year institution. Instead, cost efficiencies improved for community colleges while limiting access for a few underrepresented minority groups.

\section{Research Methods}

The Hanson-Liethen model begins with the assumption that a state has some responsibility to provide a public education to its citizens. The state, therefore, provides a base level of funding to a higher education institution, but requires some investment from the individual. The individual is given the benefit of consideration for past taxes paid to the state, meaning that the student's parents pay a tax from the time of the child's birth (0) through the age of enrolling in college (18), and that the state credits that tax base as a pre-payment for college tuition. A note should be made in this discussion that public school funding is considered separately, as public school (grades kindergarten through secondary school) are funded through local property tax, while higher education expenditures come from a payment of state personal property tax. This separation of tax funding pools may have been a particularly clear division at the time of the creation of the model, and its assumption may need to be reconsidered in future years as some states have now centralized education funding for kindergarten through college.

As a child lives in a state and the state collects property tax income from the parent, the family invests in the state to provide postsecondary education. Similarly, an individual who does not reside in a state for a long period of time prior to postsecondary enrollment pays an additional fee to cover the lack of parental property tax payment over time. The result is what is commonly referred to as a 'non-resident' tuition level. The level of tuition would presumably cover a higher proportion of the overall cost of postsecondary attendance.

The Hanson-Liethen model recognizes that citizenship is not stable, and that cross-state migration is possible and actually somewhat common. Individual state residency processes cloud the issue of who is a 'resident,' and most non-resident tuition models look no further than the year prior to postsecondary enrollment. A student could, presumably, enroll in a senior year of high school, graduate, and enroll in a state institution, paying one year of property tax and gaining the full benefit of someone who had paid 18 years of property tax.

In Hanson-Liethen, the notion of a sliding scale is introduced. The scale holds that if a 
student does not reside in the state immediately prior to entering college ( 0 years), then the student would pay $100 \%$ of a non-resident rate (total of the college experience cost [CEC] $0 \%$ of the non-resident rate [NRR]). Working with a base of 5 years, the scale 'slides' by $15 \%$ per year of residency prior to college enrollment (see Table 1).

Table 1. Hanson-Liethen sliding scale of tuition charges

\begin{tabular}{|c|c|}
\hline Length of In-State Residency & Tuition Level \\
\hline More than 5 years & In-state tuition level \\
\hline 5 years & $25 \%$ of the NRT rate \\
\hline 4 years & $40 \%$ of the NRT rate \\
\hline 3 years & $55 \%$ of the NRT rate \\
\hline 2 years & $70 \%$ of the NRT rate \\
\hline 1 year & $85 \%$ of the NRT rate \\
\hline 0 years & $100 \%$ of the NRT rate \\
\hline
\end{tabular}

One benefit of the Hanson-Liethen model is that institutions better gauge which students have paid their fair-share of state taxes, subsequently better reflecting who should receive the benefit of the in-state tuition and better using tuition as a financial tool to benefit resident students. Conversely, state residency laws and policies could impact the tuition rate payment, as a student would be able to claim state residency in some states and then begin to accrue the benefit of in-state tuition rates. For example, a first year student who moves to a state might file for residency, and in year one of college, pay the instate tuition rate plus the $100 \%$ of the non-resident tuition. If residency was granted for the second year, then the corresponding amount of tuition payment would be adjusted, garnering fewer tuition dollars for the institution.

For the sake of examining the Hanson-Liethen model, one single state institution was selected for use in examining the flow of financial data. The single-state case study method has limitations, but as Nicholson-Crotty and Meier (2002) noted, "Single state studies are appropriate ... when conditions in a given state provide a unique opportunity for the most rigorous test of a hypothesis, and when the measurement advantages of a single state study outweigh the costs of limited generalization" (p. 411).

The institution selected for study was the University of Arkansas, located in Fayetteville, Arkansas. This institution was selected for several reasons, including availability of public records, its moderate undergraduate student enrollment, its rapid enrollment growth during the past decade, and its strategic direction of enrolling a significant number of out-of-state, non-resident undergraduates.

Data from the University of Arkansas Common Data Set report indicate an undergraduate full- and part-time enrollment of 22,548 students, and the Office of Institutional Research reports that 12,254 (54\%) undergraduate students were classified as Arkansas residents for tuition purposes, with the most out of state students enrolling from neighboring Texas $(5,203$ students). 


\section{Findings}

The first step in the analysis into the benefits of the Hanson-Liethen tuition model is to establish a base tuition charge for the case study university. The University of Arkansas assesses tuition based on the number of credit hours a student enrolls in, differentiating the tuition based on undergraduate or graduate enrollment, and differentiates the total cost of attending the institution based on all considerations. The "all consideration" cost is categorized by the federal government as the "cost of attendance," (COA) and includes housing, fees, books, room, board, transportation, and an estimate for "personal" costs. An in-state tuition classified student, for example, will have a COA of $\$ 24,302$ and an out-of-state tuition classified student will have a COA of $\$ 38,650$ (both for the 2016 academic year). The COA attempts to assign a fixed cost to a variable cost, such as books and transportation. A student living 100 miles away, for example, has the same cost for transportation as the student who lives 1,000 miles away. Therefore, for the purpose of the current analysis, the actual tuition charge will be the unit of analysis used.

The case study university has six different types of undergraduate tuition, ranging from the all-university charge to charges for self-paced instruction, ranging from $\$ 130$ per credit hour to $\$ 919.54$ per credit hour. Two types of tuition were removed from the analysis, those for developmental remediation and those for self-paced instruction, resulting in the inclusion of four academic tuition charges (see Table 2). The assumption, then, is that the University of Arkansas believes the cost of providing an education is the equivalent of \$272.64 (averaged) per credit hour for an in-state (Resident) classified student and $\$ 819.30$ for an out-of-state (Non-Resident) classified student, for a difference of $\$ 546.66$ per credit hour. The annualized (30 hour total) tuition charge, then, is $\$ 8,179.20(\mathrm{R})$ as compared to $\$ 24,579(\mathrm{NR})$.

Table 2. Cost of instruction

\begin{tabular}{|l|c|c|}
\hline & In-State & Out-of-State \\
\hline General & 240.12 & 718.39 \\
\hline Business & 302.55 & 919.54 \\
\hline Architecture & 264.06 & 790.09 \\
\hline Nursing & 283.85 & 849.21 \\
\hline Average & $\mathbf{2 7 2 . 6 4}$ & $\mathbf{8 1 9 . 3 0}$ \\
\hline
\end{tabular}

Arkansas Act 1014 of 2005 restricts the length of a college bachelor's degree curriculum (with exceptions allowed) to 120 credit hours. This means that a typical $\mathrm{R}$ student will pay $\$ 32,716.80$ for a bachelor's degree (no tuition increase included) and an NR student will pay $\$ 98,316$ for the same degree, over four years.

The Hanson-Liethen model does not work in this instance, as the $\mathrm{R}$ tuition of $\$ 8,179.20$ is greater than the $25 \%$ of the NR tuition (see Table 3 ). Additionally, the case study institution charges, and is presumably able to maintain, a higher rate than the Hanson-Liethen model recommends, charging full NR students $\$ 8,220.60$ more per year. This subsequently means that the case study institution used a different model to determine the NR tuition rate, but also 
means that if the Hanson-Liethen model was adopted, the in-state tuition rate that could be charged would be hiring, thus reflecting that the institution is losing some money by not adopting the model.

Table 3. Hanson-Liethen adaptation for the University of Arkansas

\begin{tabular}{|c|c|c|c|}
\hline Residency Length & \% of NR tuition & Actual charged & Model projection \\
\hline More than 5 years & In-state & $8,179.20$ & $8,179.20$ \\
\hline 5 years & $25 \%$ & $6,144.75$ & $10,224.00$ \\
\hline 4 years & 40 & $9,831.60$ & $11,450.88$ \\
\hline 3 years & 55 & $13,518.45$ & $12,677.76$ \\
\hline 2 years & 70 & $17,205.30$ & $13,904.64$ \\
\hline 1 year & 85 & $20,892.15$ & $15,131.52$ \\
\hline 0 years & 100 & $24,579.00$ & $16,358.40$ \\
\hline
\end{tabular}

In order to determine the $\mathrm{R}$ contribution to higher education through the payment of state taxes, the state legislated tax code must first be considered. In Arkansas, personal property is taxed at the city, county, and state level, but only the state level personal tax on assessed property is included in the state fund for distribution. Certain properties are exempt, such as public, educational, faith-based, or charity properties and the assessment rate on property is $20 \%$ "of the true, actual or market value" (Assessment Coordination Department, 2012, p. 4). The state does not report an average for personal property tax assessment, so the ten highest populated cities were identified to determine a proxy average. These cities with personal property tax averages are shown in Table 3, and the average personal property tax rate for an Arkansas resident was determined to be .687 . As a caution, though, it should be noted that smaller, rural communities might have outlying taxation rates at either higher or lower levels to compensate, for example, for the need to generate more revenue to operate public services. The average personal property tax paid for the ten highest population municipalities in Arkansas was $\$ 787.30$.

Table 3. Average personal property tax rates

\begin{tabular}{|l|c|c|c|}
\hline City & Population & Average Tax Rate & Avg Personal Prop Tax Pd \\
\hline Bentonville & 44,499 & $.742 \%$ & 929 \\
\hline Conway & 64,980 & .613 & 706 \\
\hline Fayetteville & 88,194 & .707 & 909 \\
\hline Fort Smith & 88,194 & .634 & 639 \\
\hline Jonesboro & 73,907 & .548 & 572 \\
\hline Little Rock & 197,992 & .778 & 915 \\
\hline North Little Rock & 66,504 & .778 & 915 \\
\hline Pine Bluff & 44,772 & .622 & 450 \\
\hline Rogers & 63,159 & .742 & 929 \\
\hline Springdale & 77,859 & .707 & 909 \\
\hline Average & & $\mathbf{. 6 8 7}$ & $\mathbf{\$ 7 8 7 . 3 0}$ \\
\hline
\end{tabular}


Assuming a resident is born in Arkansas and lives an entire life in the same location, the family pre-college enrollment would presumably be 18 x $\$ 787.30$ to equal $\$ 14,171.40$. Additionally, the family would continue to pay property taxes even after the dependent had enrolled in college, adding another $\$ 3,149.20$ to the tax total paid, bringing a total tax payment to $\$ 17,320.60$. This tax revenue paid by the family goes into a general fund that the State policy makers to use to fund a variety of programs, including road construction and upkeep, prisons, and state contributions to federal programs such as Medicaid/Medicare.

According to a report from the Henry Kaiser Family Foundation (2016), and using 2015 data from the National Association of State Budget Officers, the Arkansas General Fund has seven primary categories. Funding to these categorical areas comprises the state budget, and includes funding for Public K-12 Education, Higher Education, Public Assistance, Medicaid, Corrections, Transportation, and Other (see Table 4). Based on these distributions in 2015, and accepting the assumption that the percentage distribution did not change significantly for 2016, the General Fund would distribute about $15 \%$ of its budget to higher education, meaning that $15 \%$ of the tax payment made by a resident would go to offset costs associated with higher education. For the resident sending a child to higher education, therefore, the contribution would be $15 \%$ of the $\$ 17,320.60$ paid in property taxes, totaling $\$ 2,598.09$.

Table 4. Arkansas general fund expenses by category, 2015

\begin{tabular}{|l|c|c|}
\hline & Dollars (in millions) & \% of General Fund \\
\hline & & $43 \%$ \\
\hline Public education & 2,181 & 18 \\
\hline Medicaid & 898 & 15 \\
\hline Higher education & 776 & 12 \\
\hline Other/discretionary & 613 & 9 \\
\hline Corrections & 438 & 3 \\
\hline Public assistance & 153 & $>1$ \\
\hline Transportation & 3 & \\
\hline
\end{tabular}

The Arkansas resident taxpayer cost of the college education, subsequently, is $\mathrm{R}=$ Tuition (total for 4 years) + taxes paid (past) + taxes paid (current @ .15 of the annual tax). Using this equation, the Arkansas resident would pay, in total for the college education, $\$ 32,716.80$ $+\$ 2,598.09+118.09(\mathrm{x} 4)=\$ 40,038.49$. Using this as a base for determining tuition according to the Hanson-Liethen model (see Table 5), the total amount would be divided by presumably four years of a college education, resulting in a base annual rate of $\$ 10,009.62$. The application of the model results in varying levels of tuition being charged, increasing by $15 \%$ per year of residency, meaning that an out of state student with no prior Arkansas residency would pay $\$ 20,109.24$ for tuition, a $\$ 4,559.76$ lower rate than its current tuition structure. 
Table 5. Hanson-Liethen application to University of Arkansas Tuition

\begin{tabular}{|c|c|c|}
\hline Residency Length & \% of NR tuition & Model charge \\
\hline More than 5 years & In-state & $10,009.62$ \\
\hline 5 years & $25 \%$ & $12,512.02$ \\
\hline 4 years & 40 & $14,013.46$ \\
\hline 3 years & 55 & $15,514.91$ \\
\hline 2 years & 70 & $17,016.35$ \\
\hline 1 year & 85 & $18,517.97$ \\
\hline 0 years & 100 & $20,019.24$ \\
\hline
\end{tabular}

As students claim in-state residency, meaning they transition from a NR classification with years of residency accumulating, they would presumably additionally begin paying some level of tax, influencing the overall public contribution to the institution. Although unlikely that a student who is enrolling in a university would pay the same level of property tax as a resident, students presumably could be purchasing housing and registering cars as personal property. Again, with an annual property tax payment of $\$ 787$, and $15 \%$ of that going to higher education $(\$ 118.05)$, the student would pay the rate of 1 year of residency $(\$ 18,517.97)$ plus the $\$ 118.05$ for a total of $\$ 18,636.02$ (assuming the student claimed instate residency during the first year of college enrollment). In this scenario, the NR student who changes classification to an instate, resident student, would pay a total of $\$ 71,422.78$ (total arrived by adding the levels of NR tuition from 0 years of residency through 3 years of residency plus the percentage of property tax paid that is contributed to higher education).

This analysis of the Hanson-Liethen model was particularly interested in addressing the following four considerations: benefit to the university, benefit to the individual, benefit to the state, and overall impact.

Financial benefit to the university: The application of the Hanson-Liethen sliding scale of tuition would not financially benefit the case study institution in terms of cash tuition collected per student, although the difference in tuition pricing could have a positive effect on enrollment numbers. The lower tuition rate could be seen as a favorable move to help recruit more students, subsequently resulting in a higher total cash tuition collected from a student body.

Financial benefit to the individual: Individual students benefit from the adoption of the Hanson-Liethen model from the perspective that there is a logical assignment of tuition costs based on state residency. An out-of-state, non-resident citizen would benefit from the adoption of the formula, as the incentive to become a resident is evident. Additionally, the state would presumably derive benefits from additional individuals becoming legal citizens, and this might impact, for example, deciding to remain in the state following graduation for work purposes, thus increasing the intellectual capital of the state's economy and compounding benefits such as the attractiveness of a state for economic development based on the number of college graduates in the population. For resident students, there is no 
change in initial tuition rates, but it does potentially add to the clarity of understanding how tuition levels are assigned.

Financial benefit to the state: As indicated, a state has the potential to benefit from the adoption of a logical model of tuition assignment. The Hanson-Liethen model creates an incentive for individuals to become citizens, and varied impacts ranging from additional intellectual capital to financial gains through taxes paid by employees could be realized. The state also potentially gains from the graduated scale of tuition payments, as it could impact the attractiveness of institutional enrollment (affordability), thus increasing enrollment, and concomitantly, institutional revenue. An area of possible new revenue for the institution could be that new residents to the state would pay a higher rate than the automatically discounted resident tuition rate, and this could be particularly financially attractive in geographic areas that import and circulate labor (individuals) at a high rate. Otherwise, these individuals would automatically be granted in-state tuition rates due to parental residency in a state.

Overall impact: The Hanson-Liethen model presents several advantages to an institution, including the presentation of a logical approach to tuition price-setting, and that issue alone may go a long way in developing trust with the public. The model does not, however, significantly change the amount of funds collected in tuition for the institution.

\section{Discussion}

The Hanson-Liethen Sliding Scale Cost Recovery Model for tuition pricing represents the idea of rationale budgeting that was popular throughout the 1970s, when it was developed. The concept of rationale budgeting is strongly tied to direct actions or purchases that are priced or associated in a logical matter with a financial commitment, and include such processes as Zero Based Budgeting. The consideration of the Hanson-Liethen model can be seen as a progressive approach to tuition setting, as it is a logical and easily explainable approach, as compared to the incremental process used in most states where tuition is increased (or decreased) simply based on a percentage tied to perceived need. Indeed, the adoption of logical model could be seen as a dramatic improvement for higher education as it attempts to explain why costs continue to rise.

In addition to linking tuition prices to a rationale, such demonstration of reasoning could positively impact student recruitment. The ability to reduce out of state tuition prices similarly could help recruit students, and the staggered approach for tuition reduction could serve as an effective tool for increasing the number of state residents. Conversely, though, a scheduled sliding tuition scale could also discourage some from attending the institution, as other strategies such as discounting tuition might be more attractive.

The largest concern for institutional leaders is that the amount of tuition that comes to the institution is not increased, and would only increase in the case of a higher volume of student enrollment. Should an institution, such as the case study institution, utilize one of the forms of out-of-state tuition waivers, then the sliding scale model proposed by Hanson-Liethen might indeed prove to be more profitable.

Overall, there needs to a more robust conversation about how tuition is managed for higher 
education institutions. The rise in tuition-free programs has prompted a public awareness that tuition pricing is somewhat 'mystical,' with little real information disclosed about calculating a true cost of educating a college student. Should higher education remain in the trend of free market competition, then tuition prices will be seen as an indicator of quality or of a perceived 'brand,' forcing students and parent to pay a price that they are willing to pay, rather than what the true cost might be. Should, however, higher education and a range of other public services be seen as a public commodity that benefits the public, then institutions will have to begin justifying their tuition as a true reflection of cost.

Further research should explore different tuition pricing models, and researchers should especially consider conducting experimental studies on the impact of tuition pricing on enrollment. Such research will better prepare the academy for the coming decades of competition for a shrinking student population.

\section{References}

Archibald, R. B., \& Feldman, D. H. (2011). Why does college cost so much? New York, NY: Oxford University Press.

Assessment Coordination Department. (2012). Frequently asked questions (2nd. Ed.). Little Rock, AR: State of Arkansas.

Baum, S., \& Lee, V. (2017). Paying for college: What is affordable? Retrieved from http://www.urban.org/sites/default/files/publication/89481/paying_for_college_finalized_0.pd $\mathrm{f}$

Burgess, B. (2009). Evaluating the policies that lead to substantial tuition variation at public land-grant universities. Unpublished doctoral dissertation, University of Arkansas, Fayetteville.

Carbone, R. F. (1974). Alternative tuition systems. Iowa City, IA: ACT Publications.

Dougherty, K. J., \& Reddy, V. (2011). The impacts of state performance funding systems on higher education institutions: Research literature review and policy recommendations. CCRC working paper no. 37. New York, NY: Community College Research Center, Teachers College, Columbia University.

Douglas-Gabriel, D. (2015, January 5). Students now pay more of their public university tuition than state governments. Washington Post. Retrieved from https://www.washingtonpost.com/news/get-there/wp/2015/01/05/students-cover-more-of-thei r-public-university-tuition-now-than-state-governments/

Doyle, W. R. (2012). The politics of public college tuition and state financial aid. Journal of Higher Education, 83(5), 617-647. https://doi.org/10.1353/jhe.2012.0033

Fincher, S. M. E. (2015). An exploration of performance-based funding at four-year public colleges in the North Central Association of Colleges and Schools. Unpublished doctoral dissertation, University of Arkansas, Fayetteville. 


\section{Macrothink}

Global Journal of Educational Studies ISSN 2377-3936 2017, Vol. 3, No. 1

Harris, M. S. (2007). From policy design to campus: Implementation of a tuition decentralization policy. Education Policy Analysis Archives, 15(16). http://dx.doi.org/10.14507/epaa.v15n16.2007

Hillman, N. W., Tandberg, D. A., \& Gross, J. P. (2014). Market-based higher education: Does Colorado's voucher model improve higher education access and efficiency? Research in Higher Education. Advance online publication. doi: 10.1007/s1162-013-9326-3

Hinrichs, P. (2017, March). Trends in revenues at US colleges and universities, 1987-2013. Economic Commentary, 2017-05. Cleveland, OH: Federal Reserve Bank of Cleveland.

Jaschik, S. (2017, April 10). New York adopts free tuition. Inside Higher Ed. Retrieved from http://www.insidehighered.com/news/2017/04/10/new-york-state-reaches-deal-provide-free-t uition-suny-and-cuny-students

Miller, M. T., \& Morris, A. A. (2008). Profile of online programs in private colleges: From college to university with a click. Academic Leadership, 6(1), Retrieved from http://www.academicleadership.org

Miller, M. T., \& Smith, E. A. (2016). Brand consciousness and college debt: Does student attendance location make a difference? International Journal of Educational Studies, 3(03), 97-103.

Mitchell, M., Leachman, M., \& Masterson, K. (2016). Funding down, tuition up: State cuts to higher education threaten quality and affordability at public colleges. Center on Budget and Policy Priorities.

Nicholson-Crotty, S., \& Meier, K. J. (2002). Size doesn't matter: In defense of single-state studies. State Politics and Policy Quarterly, 2(4), 411-422. https://doi.org/10.1177/153244000200200405

Paulsen, M. (1991). College tuition: Demand and supply determinants from 1960 to 1986. Review of Higher Education, 14(3), 339-358. https://doi.org/10.1353/rhe.1991.0017

Rusk, J. J., \& Leslie, L. L. (1978). The setting of tuition in public higher education. Journal of Higher Education, 49, 531-547. https://doi.org/10.2307/1981138

Sanford, T., \& Hunter, J. M. (2011). Impact of performance-funding on retention and graduation rates. Education Policy Analysis Archives, 19(33), 1-30. http://dx.doi.org/10.14507/epaa.v19n33.2011

Smith, A. A. (2017, March 24). Indiana creates free tuition program for certificate earners. Inside Higher Ed. Hetrieved from http://www.insidehighered.com/news/2017/03/24/indiana-creates-free-tuition-program-certifi cate-earners

Western Interstate Commission for Higher Education (2009). An evaluation of Colorado's College opportunity fund and related policies. Retrieved from Western Interstate Commission for Higher Education http://www.wiche.edu/pub/12271 


\section{Copyright Disclaimer}

Copyright for this article is retained by the author(s), with first publication rights granted to the journal.

This is an open-access article distributed under the terms and conditions of the Creative Commons Attribution license (http://creativecommons.org/licenses/by/3.0/). 